\title{
Critical Reception of the House of the Seven Gables in Western countries and China
}

\author{
Li Xia
}

College of Foreign Studies, Weinan Teachers’ University, Weinan Shaanxi, 714000

Keywords: The House of the Seven Gables, literary criticism, diversity, deficiency, eternity

\begin{abstract}
The House of the Seven Gables was once viewed as the best of Hawthorne's novels at his time. Despite the later revise of the evaluation, the House still enjoys a high reputation among Hawthorne's literary works. The paper is intended to have a historical look at of critical reception of The House in western countries and in China, which helps readers gain a better insight into the cumulative richness of this novel over time.
\end{abstract}

\section{Introduction}

Nathaniel Hawthorne (1804-1864), one of the most original and influential writers in American literature, has contributed to America and the whole world with excellent writings, including four novels: The Scarlet Letter(1850), The House of the Seven Gables (1851), The Blithedale Romance(1852) and The Marble Faun(1860); three collections of short stories: Twice Told Tales(1837), Mosses from an Old Manse(1846); The Snow-Image and Other Twice Told Tales(1851), and two collections of fairy tales: A Wonder Book for Girls and Boys(1852) and Tanglewood Tales for Girls and Boys (1853)

The House of the Seven Gables, Hawthorne's second novel, is composed about six months after the publication of The Scarlet Letter on March 16, 1850, and is completed on January 12, 1851. Only in about five months, Hawthorne produced this great work which he himself repeatedly expressed a preference over his earlier work. In his words, The House of the Seven Gables was a work "more characteristic" of his mind and "more proper and natural for him to write"(Stewart 112). During Hawthorne's lifetime, The House was generally viewed as the best of his novels.

Hawthorne's preference for the House is shared by many critics since its publication. Edwin Percy Whilpple, one of well-known critics of Hawthorne's time, praised highly of Hawthorne's accomplishment in the novel and thought it Hawthorne's greatest work that deserved immediate popularity and permanent fame. However, other critics have ranked it behind The Scarlet Letter mainly because of its lack of unity and the flawed ending. In contrast to the extensive study of The Scarlet Letter that earns Hawthorne's national and worldwide reputation, The House of the Seven Gables indeed prompted a relatively smaller number of critical essays. Nevertheless, The House of the Seven Gables continues to attract the interests and attention from both public readers and literary critics for its richly portrayed characters, multiple levels meanings and ambiguity.

\section{Critical Reception of the House in Western countries}

Literary criticism on The House of the Seven Gables chronologically can be roughly divided into the following four periods:

Criticism in Hawthorne's time. The critical achievements of this period mainly include: in the letter to Hawthorne, Herman Melville believed The House surpassed the other works of the author and celebrated Hawthorne’s “power of blackness” (258) ;Edwin Percey Whipple made enthusiastic and favorable comments on the work, saying that this greatest work was characteristic of strikingly original imagination and exquisitely carved characters.(169); Henry Tucherman , whom Hawthorne considered to be the one looking into his book and knowing what he meant, concluded that the romance was imbued with a local authenticity through a detailed analysis of the scenery, tone and personages of the story (327) . In contrast to these appreciative comments on The House, there were 
still unfavorable opinions from Hawthorne's contemporaries. For instance, Catharine Maria Sedgwick, one of the renowned novelists at that time expressed her negation of the work, thinking it to be a failure for its too much gloomy elements for the subject and for its lack of essentials of a work of art (320). Nevertheless, The House was hailed as another success by the majority of Hawthorne's contemporaries.

Criticism from Hawthorne's death to 1914. The critical achievements of this period mainly include: Anthony Trollope's depreciating comments on the less artistic skills employed in the novel, complaining that Hawthorne has labored over the plot of the story and never had it clear to his own mind (332). Another representative literary criticism on The House at this period was made from Henry James. Though pointing out that the work was the more elaborate and imaginative than Hawthorne's other works, James believed it to be filled with fragments, less rounded and complete than its predecessor The Scarlet Letter (335). William Dean Howells even criticized the novel as the most tiresome one among Hawthorne's other books for its straggling form and lack of vitalities in characters (339). In general, criticism in this period tends to identify the flaws and weakness of the novel from the perspective of artistic accomplishments.

Criticism from 1914 to 1964. F.O. Matthiessen, one of the foremost critics in American literature, explored the cultural and historical implications displayed in The House through a detailed discussion on the themes, characters, and conclusion of the story. He diagnosed the real curse on the Pynchon's family as their drive for power, the material property and ignorance of the prevailing democratic concept of that age (173). Another critical view on the novel from Austin Warren is noteworthy for it was the first comparatively thorough study of defects in the plot, structure and characterizations of The House (178). Darrel Abel's examination of novel's structure is also well worth mentioning in that it may be the representative of negative opinions towards the organizing principles in The House. According to Abel, there was no plotted development in the story and the narrative leapt over pages with apparent arbitrariness. He further illustrated that the book was filled with a series of minor, quite static and discursive situations without any dynamic situation cultivating in a crisis (184). Randall Stewart also cannot be ignored for the study of this critical period because he had written numerous articles on as well as a biography of Hawthorne and his works. It was Stewart who examined Hawthorne's view on the relationships between person and person and individual to society. The latter, in particular, works as a stimulus for the writing of this thesis in which investigations will be conducted to analyze the estranged relationship experienced by the individual from the others and the circumstances. To sum up, the critics of this period continued to focus on multiple themes, the narrative forms and artistic techniques exhibited in the novel.

Criticism from 1964 to the present. With the application of new perspectives and disciplinary knowledge to the study of Hawthorne's works, some literary critics attempted to reread the story and reevaluate the achievement of The House of the Seven Gables. Frederick C. Crew applies the psychoanalytic method to conclude that Judge Pyncheon represents a hatred father figure at the plot and his death set free his symbolically children-Hepzibah and Clifford (175). Michael T. Gilmore comments that The House is a reflection of Hawthorne's compromise of his artistic independence and integrity with the general public marketplace (348). Walter Benn Michaels whose study was made on the racial issue displayed in the fiction, and Gillian Brown examines women's domestic activities and a change in women's work.

\section{Critical Reception of the House in China}

In the critical study of Hawthorne's works and his literary accomplishments in China, attention has long been focused on The Scarlet Letter that earns him national and worldwide fame as a renowned and original American writer. The Scarlet Letter has become the one most scholars and critics must mention and analyze in their study of Hawthorne's works whatever their approaches might be. In contrast, The House of the Seven Gables has prompted the relatively smaller number of critical studies, and less attention has been paid in this book in China, which can be reflected in the small quantity of the transltion of and academic articles on this work. Before 1970s, the 
introduction to Hawthorne's works was mainly about the translation and interpretation of the novel the Scarlet and a few short well- known stories.Until now, only three Chinese versions of The House of the Seven Gables are available in the Chinese book market One was translated by Jia Wenhao \& Jia Wenyuan in 2001. The other two are translated by Wang Huijun \& Wang Huiling in 2003 and by Li Yingcheng in 2012 respectively. In addition, The original English version of the House is no easy to come by in most Chinese book stores,too. When it comes to the academic articles directly related to this book, a surprising small number of some less than twenty essays could be found from CNKI from 1995 to 2016 in China,which might be shown by the statistics chart below, surveyed from CNKI database.

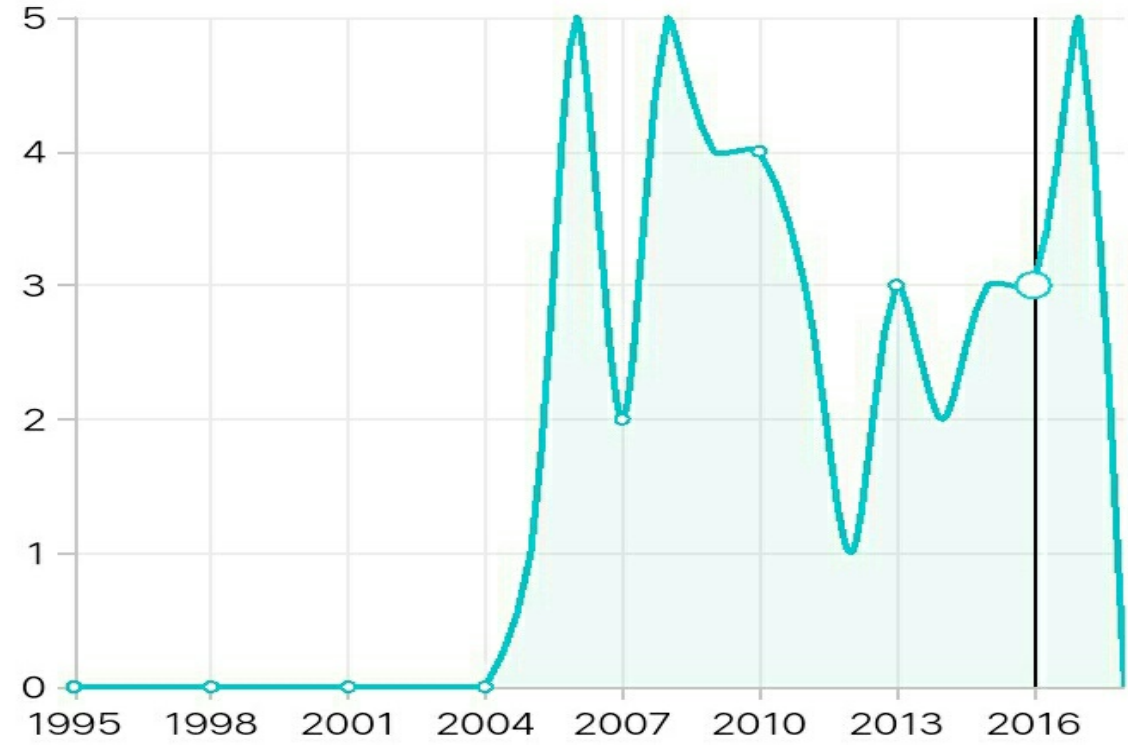

Figure.1

From the chart, we can see no critical comments on the House were released during a decade from 1995 to 2004; there are ups and downs in the total quantity of the published articles per year from 2005 to 2016; and the summit number of publication is up to 5 essays in a year. Judging from these data, an apparent conclusion can be drawn that in China less attention has been paid on The House of the Seven Gables in contrast to extensive study in western countries. Among the published literary criticism, two articles by Zhen Li-Li and one by Dong Lan, "On Symbolism in The House of the Seven Gables", centers on the special symbolic meanings of concrete objects, settings and characters which are amply applied in the book; and two papers written by Xu Qian and Fang Wen-Kai examine literary creation and function from Hawthorn's writing styles and his relevant aesthetic views. Another two essays written by Zhang Wen and Li Zheng are made in an analysis of the mystery in The House of the Seven Gables and the gothic elements employed in the exhibition of the setting, characters, plot and theme of the novel. In addition, one article byYang Gen-Hua is composed on the measurement of narrative skills from the perspective of Hawthorne's male gender status; and one essay by Fang Wen-Kai is on the study of Arabesque narrative structure in this work. In contrast to these nine articles that focus on the artistic accomplishments displayed in the novel, the other five articles are made on the examination of the central theme in the book, among which the writings of Zhang Jun-Hua and Zhang Xi attempt to explore the theme of religious morality in Hawthorne's book; one essay made by Wang Zi-Hong is on the exploration of the emerging controversial new concepts as well as the serious social problems in the nineteenth-century American society. And the paper written by Hou Bin is about loneliness and alienation presented in the work. Through a heavy analysis of Hepzibah and Clifford, Hou Bin intends to detect the modernity reflected in the work. In his paper, Hou Bin, mainly focuses on Hepzibah and Clifford, lacking a detailed study of other characters.

To sum up, the articles mentioned above cover a limited scope of the topics and perspectives, including traditional narrative elements such as plot, theme, characters, structure and environmental; asthetic devices such as symbolism, mysticism and Gothic characteristic; and a focus on the study 
of the author himself, such as Hawthorne's cultural and political strategies, his Puritan ideologies as well as his aesthetic belief and innovation.

\section{Conclusions}

Hawthorne himself, however, repeatedly commented that he preferred it to the earlier romance and believed it to be the best of all his works. When he wrote to the publisher Fields, Hawthorne explicitly showed his expectation of the work's great success by predicting that The House must oversell his previous work The Scarlet Letter. (Myerson 149). In the letter to his sister Elizabeth about this work, he commented that The House had more merits than The Scarlet Letter (Myerson 152). Hawthorne's special preference and the fourising foreign study of the novel make a sharp contrast with the severe deficiency in the critical reception of the House in China, which seems not to match the reputation of this book in the history of American literature.

Although being inadequate and unsatisfactory in contrast to the blossoming foreign study of the House, the current academic research of the book in China presents a trend of diversification in its interpretation and a variety of such modern criticism as new historicism, archetypal criticism; psychoanalysis are increasingly applied to the House. With the introduction of more interdisciplinary perspectives and approaches, Chinese literary criticism on the House will be futhered and fully enriched. In conclusion, interpretaion of The Housevvary from country to country, and from age to age owing to its own cultural and critical estimations, which must have a gradual shift over time. However, no matter what literary schools have developed, and no matter how literay reception has ever changed, generations of critics never lose their great interest in The House and its artistic charm shines with eternity.

\section{References}

[1] Abele, Rudolph Van. "On Irony in the House of the Seven Gables." Nineteenth-Century Literature Criticism. Ed. Joann Cerrito. Detroit: Gale Research Inc., 1993.184

[2] Bercovitch, Sacvan, ed. Cambridge History of American Literature. Vol.2. New York: Cambridge Uni. Pr., 1995.

[3] Buitenhuis, Peter. The House of the Seven Gables: Serving Family and Colonial Ties. Boston: Twayne Publishers, 1991.

[4] Cerrito, Joann, ed. Nineteenth-Century Literature Criticism. Vol.39.Detroit: Gale Research Inc., 1993.

[5] Cohen, B. Bernard, Ed. The Recognition of Nathaniel Hawthorne-Selected Criticism Since 1828. Ann Arbor: The University of Michigan Press, 1969.

[6] Crews, Frederick C. The sins of the fathers: Hawthorne University of California, 1989.

i. Herman Melville, "Hawthorne and His Mosses” Ed. Donohue, A. M 258

[7] Hawthorne, Nathaniel Selected letters of Nathaniel Hawthorne, Ed. Joel Myerson, Columbus: Ohio State University Press, 2002.

a) The House of the Seven Gables. KuiTun: Yi Li People’s Press, 2002.

[8] Hoeltje, Hubert. Inward sky the mind and heart of Nathaniel Hawthorne. Durham, N.C.Duke University Press, 1962.

i. Howells, William Dean. “Dim, Forlorn Wraiths.” Levine 339

b) James, Henry “On Hawthorne’s The House.” Levine 336

[9] Levine, Robert, ed. Nathanial Hawthorne The House of the Seven Gables An Authoritative Text Biographical and Historical Contexts Criticism New York: W•W• Norton\&Company, 1994. 
[10] Long, Amy Schrager. “The readings of Hawthorne's the House of the Seven Gables.” Levine 464

1. Matthiessen, F.O. "On the House of the Seven Gables”, Cerrito 173

[11] Reynolds, Larry J., A Historical Guide to Nathaniel Hawthorne Oxford; New York: Oxford University Press, 2001.

1. Sedgwick, Catharine Maria. "Letter to Mrs. .K. S. Minot.” Levine 320

ii. Stewart, Randall, Nathaniel Hawthorne: a biography. New Haven: Yale University Press, 1948.

1. Trollope, Anthony. "The Genius of Nathaniel Hawthorne.” Levine 332

2. Tucherman, Henry. "Nathaniel Hawthorne” Levine 327.

3. Warren, Austin. "On the House of the Seven Gables.” Cerrito 178.

4. Whipple, Edwin Percey. "On the House of the Seven Gables.” Cerrito 169.

[12] Dong Lan. “Symbolism in Hawthorn's the House of the Seven Gables”.Journal of University of International Relations, 1997 (02).

[13] Fang Wenlai. “On Nathaniel Hawthorne's Cultural-Political Strategy In The House of the Seven Gables”. Foreign Literature Studies 2008(01).

[14] Fang Wenlai. “On the Arabesque Structure of Hawthorne's The House of the Seven Gables”.Journal of Sichuan International Studies University, 2008(06).

[15] Li Zheng. “Gothic Elements in Hawthorn's the House of the Seven Gables”. Journal of Taiyuan Urban Vocational College, 2006(01).

[16] Hou Bin. "Isolation and Alienation in the House of the Seven Gables and Its Modernity". Journal of Yili Normal University (Social Science Edition), 2010(01).

[17] Xu Qian. “Hawthorn's aesthetieinclination in the HouseoftheSevenGable”. The Public Art and Literature Magazine 2008(07).

[18] Zhen Lili. “On Symbolic presentation in Hawthorn's the House of the Seven Gables”. Journal of Lanzhor University (Social Sciences) 1995(04).

[19] Zhen Lili. “Again on Symbolic presentation in Hawthorn's the House of the Seven Gables”. Journal of Taiyuan Normal University:Social Science Edition, 1995(02).

[20] Zhang Xi. "On the study of sins in the House of the Seven Gables”. Teach Yourself English, 2003(02).

[21] Zhang Junhua. "Exploration of Sins in the House of the Seven Gables". Masterpieces Review, 2007(18).

[22] Zhang Wen. "An Analysis of the Mystery in the House of the Seven Gables". Journal of Yangtze University (Social Sciences Edition), 2006(01).

[23] Yang Genhua. "Male Narrative in The House of the Seven Gables". Writer Magazine, 2009(10).

[24] Wang Ziwen. "The House of the Seven Gables:a romantic interpretation of social history”.Journal of Anhui University of Science and Technology(Social Science) 2, 2006(04)

[25] WU Jinhong. "A Reflection on the Evil of Human Nature-The Biblical Images in The House of the Seven Gables”. Journal of North University of China(Social Science Edition) 2015(12) 